\title{
EVALUATION OF THE ROLE OF DR JOSHI'S EXTERNAL FIXATOR IN MANAGEMENT OF COMPLEX AND COMPOUND MUTILATING INJURIES OF HANDS AND FOREARM.
}

Amit Sehgal, Paras Gupta, Madhusudan Mishra, Chavi Sethi, Rupesh Kumar
1. Consultant. Department of Orthopaedics, MLB Medical College, Jhansi, Uttar Pradesh.
2. Assistant Professor. Department of Orthopaedics, MLB Medical College, Jhansi, Uttar Pradesh.
3. Junior Resident. Department of Orthopaedics, MLB Medical College, Jhansi, Uttar Pradesh.
4. Lecturer. Department of Anaesthesia, MLB Medical College, Jhansi, Uttar Pradesh.
5. Assistant Professor. Department of Anaesthesia, MLB Medical College, Jhansi, Uttar Pradesh.

\section{CORRESPONDING AUTHOR: \\ Dr . Amit Sehgal, \\ J-41 Ajay Enclave, \\ Mahakali Vidhyapeeth Road, \\ Jhansi-284002. \\ E-mail: dr_chavi@yahoo.com}

INTRODUCTION: The human body is an amalgamation of many fundamental units put together. Amongst these hands have got a very distinct and important role. Injuries, diseases, and surgical interference therefore do much more harm than interfere with grip, touch, it expresses the personality itself. In disabilities of the Hands, the finest surgery and after care is more essential than in any other region of the body.

JOSHI'S EXTERNAL STABILIZING SYSTEM, (JESS), provides a stable skeletal environment aiding rapid healing of soft tissue with establishment of microvascular circulation, immediate active and passive mobilization of the uninjured adjacent joints. It allows management and care of soft tissue injuries without disturbing the fracture site in compound injuries, which is not possible using other methods.

AIMS AND OBJECTIVES: Evaluation of the role of Dr Joshi's external fixator in management of complex and compound mutilating injuries of hands and forearm.

MATERIALS \& METHODS: 40 cases of injuries of hand and forearm attending Orthopaedic OPD and Emergency Department of Orthopedics, M.L.B. Medical College, Jhansi between feb 2010 to feb 2012 were treated by Joshi's external stabilizing system. The patients were followed at regular interval and the results were evaluated clinically and radiographically.

CRITERIA FOR SELECTION OF PATIENTS: All the patients of open/closed fractures of metacarpals and phalanges of hand irrespective of age and sex willing to undergo this procedure were selected with permission of ethical committee of medical college.

PREOPERATIVE ASSESSMENT OF HAND: Done with

1. History

2. Routine investigations

3. Pre-operative X-rays - AP, lateral/oblique view. 


\section{CLASSIFICATION OF BONE INJURIES :}

A1.Simple 2.Compound

B1.Noncomminuted 2.Comminuted

C1.Intraarticular 2.articular

\section{PRINCIPLE OF MANAGEMENT:}

1. Stable reduction, anatomical when possible.

2. Maintenance of length and rotation of digit.

3. Appropriate care of associated soft tissue injuries.

4. Mobilization of uninvolved digits and adjacent joints.

5. Prevention of lymph and venous stasis.

6. Ability to add dynamic component into the frame and permit concurrent mobility of the joints of the injured limb

\section{Basic Components of JESS}

1. Alpha clamp

2. Beta clamp

3. Connecting rods

4. Krishner wires $-1.2 \mathrm{~mm}, 1.5 \mathrm{~mm}$ and $2.0 \mathrm{~mm}$ K-wires with $15 \mathrm{~cm}$ and $20 \mathrm{~cm}$ length.

5. Distraction and compression external fixators

\section{Instrumentation}

2. Hand drill (Electrical, pneumatic or mechanical).

3. T-Handle with chuck.

4. A pair of pliers

5. Wire cutters

6. Allen keys $2.5 \mathrm{~mm}$ and $3 \mathrm{~mm}$

7. Rod benders.

\section{Main aim of follow up -}

1. Assessment of functions

2. Stability of apparatus

3. Complications, if any

4. Advise regarding physiotherapy

5. To see for union

Results will be evaluated on the criteria's laid down:

\begin{tabular}{|l|l|}
\hline Diff. in AROM at MP Joint & Points \\
\hline No Difference & 4 \\
\hline $0-30^{\circ}$ & 3 \\
\hline $30-60^{\circ}$ & 2 \\
\hline$>60^{\circ}$ & 1 \\
\hline
\end{tabular}

\begin{tabular}{|l|l|}
\hline Diff. in AROM at DIP joint & Points \\
\hline No differance & 4 \\
\hline $0-15^{\circ}$ & 3 \\
\hline
\end{tabular}




\begin{tabular}{|l|l|}
\hline $15-30^{\circ}$ & 2 \\
\hline$>30^{\circ}$ & 1 \\
\hline
\end{tabular}

\begin{tabular}{|c|c|}
\hline Diff. in AROM at DIP joint & Points \\
\hline No differance & 4 \\
\hline $0-50^{\circ}$ & 3 \\
\hline $50-100^{\circ}$ & 2 \\
\hline$>100^{\circ}$ & 1 \\
\hline
\end{tabular}

\begin{tabular}{|l|l|}
\hline $\begin{array}{l}\text { Grip strength as compared to normal } \\
\text { hand }\end{array}$ & Points \\
\hline Normal & 4 \\
\hline Mild deficiency & 3 \\
\hline Moderate " & 2 \\
\hline Severe " & 1 \\
\hline
\end{tabular}

\begin{tabular}{|l|l|}
\hline Results & Points \\
\hline Excellent & $52-64$ \\
\hline Good & $40-51$ \\
\hline Fair & $28-39$ \\
\hline Poor & $16-27$ \\
\hline
\end{tabular}

Observation: The study is based on the observations of 40 cases of hand and forearm injuries admitted in Department of Orthopedics, M.L.B. Medical college, Jhansi.

\section{TABLE NO. - 1 INCIDENCE IN DIFFERENT AGE GROUPS}

\begin{tabular}{|l|l|l|l|l|}
\hline \multirow{2}{*}{ Age in yrs. } & \multicolumn{2}{l|}{ Male } & \multicolumn{2}{l|}{ Female } \\
\cline { 2 - 6 } & No. & $\%$ & No. & $\%$ \\
\hline $10-20$ & 06 & 16.67 & -- & -- \\
\hline $21-30$ & 12 & 33.33 & 1 & 25.00 \\
\hline $31-40$ & 14 & 38.89 & 1 & 25.00 \\
\hline $41-50$ & 03 & 08.33 & -- & -- \\
\hline $51 \&$ above & 01 & 02.78 & 2 & 50.00 \\
\hline Total & 36 & 100.00 & 4 & 100.00 \\
\hline
\end{tabular}

The incidence of injury was varying in different age groups. Majority of male patients were between 31-40 years of age, while female patients were $>50$ years of age. The mean age in our study was 32 years.

TABLE NO. - 2 (SEX INCIDENCE IN TOTAL PATIENTS)

\begin{tabular}{|l|l|l|}
\hline Sex & No. Of cases & $\%$ \\
\hline Male & 36 & $90 \%$ \\
\hline Female & 4 & $10 \%$ \\
\hline Total & 40 & 100 \\
\hline
\end{tabular}

There were 36 males (90\%) \& 4 females (10\%) included in the study. 
TABLE NO -3 (DURATION OF INJURY IN DIFFERENT CASES)

\begin{tabular}{|l|l|l|l|}
\hline S. No. & Duration & Cases & $\%$ \\
\hline 1 & $<1$ day & 22 & 55 \\
\hline 2 & $1-5$ day & 14 & 35 \\
\hline 3 & $6-10$ day & 02 & 5 \\
\hline 4 & $11-15$ day & 01 & 2.5 \\
\hline 5 & $16-30$ day & -- & -- \\
\hline 6 & $31-90$ day & -- & -- \\
\hline 7 & $>90$ day & 01 & 2.5 \\
\hline & Total & 40 & 100 \\
\hline
\end{tabular}

Maximum number (55\%) of patients present on the same day of injury while $90 \%$ of patients present within 5 days of injury.

\section{TABLE NO-4 (MODE OF INJURY IN DIFFERENT CASES)}

\begin{tabular}{|l|l|l|l|}
\hline S. No. & Mode of injury & No. of patients & $\%$ \\
\hline 1. & Thresher or machine injury & 10 & 25 \\
\hline 2. & Road traffic accidents & 10 & 25 \\
\hline 3. & Fall of heavy objects & 08 & 20 \\
\hline 4. & Fire- arm injury & 05 & 12.5 \\
\hline 5. & Blast injury & 02 & 05 \\
\hline 6. & Others & 05 & 12.5 \\
\hline Total & 40 & 100 \\
\hline
\end{tabular}

Most common mode of injury in our study was thresher injury \& road traffic accidents followed by fall of heavy objects.

TABLE NO. 5 TYPE OF WOUND

\begin{tabular}{|l|l|l|}
\hline Type of wound & No. Of patients & $\%$ \\
\hline Crushed & 18 & 52.94 \\
\hline Lacerated & 15 & 44.12 \\
\hline Incised & 01 & 02.94 \\
\hline Total & 34 & 100.00 \\
\hline
\end{tabular}

Wounds were crushed in 53\% patients, while lacerated in $44 \%$ of cases.

TABLE NO. - 6 (CONDITION OF INJURED PART)

\begin{tabular}{|l|l|l|l|}
\hline S. No. & Condition & No. of cases & $\%$ \\
\hline 1. & Open & 34 & 85 \\
\hline 2. & Closed & 06 & 15 \\
\hline Total & & 40 & 100 \\
\hline
\end{tabular}

Out of 40 patients, 34 patients (85\%) have open type fracture. 
TABLE NO. -7 SEVERITY OF WOUND

\begin{tabular}{|l|l|l|l|}
\hline Grade & I & II & III \\
\hline Cases & 01 & 14 & 19 \\
\hline
\end{tabular}

Out of 34 patients having open type fractures, 19 have type III compounding injury.

TABLE NO. - 8A PATTERN OF INVOLVEMENT OF BONES AMONG PATIENT.

\begin{tabular}{|l|l|l|l|}
\hline S. No. & Bones involved & No. of patients & $\%$ \\
\hline 1 & Both bone forearm & 04 & 10 \\
\hline 2 & Metacarpal & 09 & 22.5 \\
\hline 3 & Phalanges & 13 & 32.5 \\
\hline 4 & Combined & 14 & 35 \\
\hline Total & 40 & 100.0 \\
\hline
\end{tabular}

More then one group of bones were involved in 35\% of cases in our study, while isolated fractures of phalanges \& metacarpal were present in $32.5 \& 22.5 \%$ of cases, respectively.

TABLE No. $-8 B$

\begin{tabular}{|l|l|l|l|}
\hline S. No. & Bones involved & No of fractures & Percentage \\
\hline 1. & Phalanges & 32 & 32 \\
\hline 2. & Metacarpal & 50 & 50 \\
\hline 3. & Radius & 09 & 09 \\
\hline 4. & Ulna & 09 & 09 \\
\hline Total & 100 & 100 \\
\hline
\end{tabular}

Metacarpals fractured in maximum cases of combined injury that's why metacarpals share $50 \%$ of total no of bone fractured in our study.

TABLE NO. - 9 PATTERN OF JOINT INVOLVEMENT AMONG PATIENTS

\begin{tabular}{|l|l|l|l|}
\hline S. No. & Joint involved & No. of joints involved & $\%$ \\
\hline 1. & MP & 16 & 34.78 \\
\hline 2. & PIP & 04 & 08.70 \\
\hline 3. & DIP & 03 & 06.52 \\
\hline 4. & IP & 07 & 15.22 \\
\hline 5. & WT & 16 & 34.78 \\
\hline & Total & 46 & 100.0 \\
\hline
\end{tabular}

MP joint \& wrist joints were commonly involved joints in our study because metacarpals were involved in large number.

TOTAL NO. - 10 TYPE OF JESS FRAME APPLIED IN ALL PATIENTS

\begin{tabular}{|l|l|l|l|}
\hline S. No. & Type of JESS frame & No. of cases & Percentage \\
\hline 1. & Distractor & 11 & 27.5 \\
\hline 2. & Extended hand frame & 05 & 12.5 \\
\hline 3. & Basic hand frame & 04 & 10.0 \\
\hline 4. & Ray frame & 04 & 10.0 \\
\hline
\end{tabular}




\begin{tabular}{|l|l|l|l|}
\hline 5. & $1^{\text {st }}$ web space frame & 04 & 10.0 \\
\hline 6. & Forearm frame & 02 & 5.0 \\
\hline 7. & "U" /"L" frame & 04 & 10.0 \\
\hline 8. & Metacarpal hold & 04 & 10.0 \\
\hline 9. & Biplanner frame & 01 & 2.5 \\
\hline 10. & Bennett's fracture frame & 01 & 2.5 \\
\hline Total & 40 & 100.0 \\
\hline
\end{tabular}

Various types of JESS frame were applied in our study, but different distracters (29.5\%) were applied the most.

TABLE NO. - 11 COMPLICATION

\begin{tabular}{|l|l|l|l|}
\hline S. No. & Complications & No. & $\%$ \\
\hline 1. & Pin tract infections & 04 & $10.0 \%$ \\
\hline 2. & Osteomyelitis & 06 & $15.0 \%$ \\
\hline 3. & Deformity & 18 & $45.0 \%$ \\
\hline 4. & Non- union & 03 & $7.5 \%$ \\
\hline 5. & Delayed- union & 02 & $5.0 \%$ \\
\hline 6. & Swelling & 10 & $25.0 \%$ \\
\hline 7. & Skin- necrosis & 08 & $20.0 \%$ \\
\hline 8. & Pain & 10 & $25.0 \%$ \\
\hline 9. & Loosening of joints & 02 & $5.0 \%$ \\
\hline 10. & Loosening of k-wires & 05 & $12.5 \%$ \\
\hline 11. & Contractures & 01 & $2.5 \%$ \\
\hline
\end{tabular}

The most common complication encountered in our study was deformity in $45 \%$ of cases followed by swelling and pain.

TABLE NO. - 12 (OPERATION PROCEDURE REQUIRED IN MANAGEMENT)

\begin{tabular}{|l|l|l|l|}
\hline S. No. & Operation/ procedure required & No. & \\
\hline 1. & Debridement \& ext. fixation without distraction & 26 & $65.0 \%$ \\
\hline 2. & Debridement \& ext. fixation with distraction & 08 & $20.0 \%$ \\
\hline 3. & Distraction/ compression & 12 & $30.0 \%$ \\
\hline 4. & POP immobilization & 19 & $47.5 \%$ \\
\hline 5. & Split thickness skin grafting & 04 & $10.0 \%$ \\
\hline 6. & Bone grafting & 03 & $7.5 \%$ \\
\hline 7. & Internal fixation & 08 & $20.0 \%$ \\
\hline 8. & Sequestrectomy & 06 & $15.0 \%$ \\
\hline 9. & Tendon repair & 08 & $20.0 \%$ \\
\hline 10. & Myoplasty & 04 & $10.0 \%$ \\
\hline 11. & Contracture release/ Z-plasty & 01 & $2.5 \%$ \\
\hline 12. & Corrective osteotomy & 02 & $5.0 \%$ \\
\hline
\end{tabular}


TABLE NO. - 13 (CONDITION OF WOUND AT THE TIME OF REMOVAL OF FIXATOR)

\begin{tabular}{|c|c|c|c|}
\hline S. No. & Status & No. & Percentage \\
\hline 1. & Healed & 29 & 75.50 \\
\hline 2. & Not healed & 11 & 27.50 \\
\hline \multicolumn{2}{|l|}{ To } & 40 & 100.00 \\
\hline
\end{tabular}

In $72.5 \%$ of cases fixator was removed after complete healing of wound while in $27.5 \%$ cases it was removed before healing of wound.

TABLE NO. - 14 (TIME OF FIXATOR REMOVAL)

\begin{tabular}{|l|l|l|l|}
\hline S. No. & Duration in days/ wks/ months & Cases & Percentage \\
\hline 1. & Less than $<28$ days $(4$ wks) & 05 & 12.5 \\
\hline 2. & $29-42$ days (up to 6 wks) & 15 & 37.5 \\
\hline 3. & $43-60$ days (up to 2 months $)$ & 11 & 27.5 \\
\hline 4. & $60-90$ days (up to 3 months $)$ & 05 & 12.5 \\
\hline 5. & $>90$ days $(>3$ months $)$ & 04 & 10.0 \\
\hline Total & 40 & 100.00 \\
\hline
\end{tabular}

In $50 \%$ of cases fixator was removed with in 6 weeks while in $78 \%$ cases it was removed in 8 weeks of fixator application.

TABLE NO. - 15 (TIME OF WOUND HEALING)

\begin{tabular}{|l|l|l|l|}
\hline S. No. & Duration & Cases & Percentage \\
\hline 1 & Upto15 days & 06 & 17.65 \\
\hline 2 & $15-30$ days & 13 & 38.24 \\
\hline 3 & $30-60$ days & 07 & 20.59 \\
\hline 4 & $60-90$ days & 04 & 11.76 \\
\hline 5 & $>90$ days & 04 & 11.76 \\
\hline \multicolumn{2}{|l|}{ TOTAL } & 34 & 100.00 \\
\hline
\end{tabular}

Wounds were healed in $48 \%$ of cases with in 30 day.

TABle NO. - 16 (Period Of Hospitalisation)

\begin{tabular}{|l|l|l|l|}
\hline S. No. & Duration in days & Cases & $\%$ \\
\hline 1. & $<3$ & 06 & 15.0 \\
\hline 2. & $4-7$ & 07 & 17.5 \\
\hline 3. & $8-14$ & 10 & 27.5 \\
\hline 4. & $15-30$ & 13 & 30.0 \\
\hline 5. & $>30$ & 04 & 10.0 \\
\hline Total & 40 & 100.00 \\
\hline
\end{tabular}

Majority of male patients were between 31-40 years of age, while female patients were > 50 years of age. The mean age in our study was 32 years.

There were 36 males $(90 \%) \& 4$ females $(10 \%)$ included in the study.

Maximum number (55\%) of patients present on the same day of injury while $90 \%$ of patients present within 5 days of injury. 
Most common mode of injury was thresher injury \& road traffic accident.

Wounds were crushed in $53 \%$ patients, while lacerated in $44 \%$ of cases.

Out of 40 patients, 34 patients (85\%) have open type fracture.

19 have type III compounding.

More than one group of bones were involved in $35 \%$ of cases while isolated fractures of phalanges \& metacarpal in $32.5 \& 22.5 \%$ of cases, respectively.

MP Joint \& wrist joints were commonly involved joints.

Various types of JESS frame were applied in our study.

Most common complication encountered in our study was deformity in $45 \%$ followed by swelling and pain.

In $72.5 \%$ of cases fixator was removed after complete healing of wound.

In $50 \%$ of cases fixator was removed within 6 weeks while in $78 \%$ cases it was removed in 8 weeks of fixator application.

Wounds were healed in $48 \%$ of cases with in 30 day.

Maximum numbers of patients were discharged within 30 days of hospitalization.

\section{RESULTS:}

- At the time of fixator removal full movements were regained at $42.5 \%$ of MP Joints, $42.5 \%$ IP joint, $51.88 \%$ of PIP joints, $56.88 \%$ of DIP joints, $40 \%$ of wrist joint, $51 \%$ of MP joints.

- At the time of final follow up 67.5\% of IP joint, $69.38 \%$ of PIP joint, $74.38 \%$ of DIP joint, $57.5 \%$ of wrist joints regained full movements.

- The grip strength of final fallow up was normal in $50 \%$ of cases while mildly deficient in $30 \%$ of cases.

TABLE NO. - 17 (RESTRICTIONS IN RANGE OF MOVEMENTS OF MP JOINT AT THE TIME OF FIXATOR REMOVAL)

\begin{tabular}{|l|l|l|l|l|l|l|}
\hline S. No. & & 1. & 2. & 3. & 4. & 5. \\
\hline 1. & No difference & 12 & 14 & 19 & 20 & 20 \\
\hline 2. & $0-30^{\circ}$ & 16 & 11 & 09 & 08 & 08 \\
\hline 3. & $30-60^{\circ}$ & 10 & 10 & 08 & 08 & 07 \\
\hline 4. & $60-90^{\circ}$ & 02 & 05 & 04 & 04 & 05 \\
\hline
\end{tabular}

At the time of fixator removal full movements were regained at $42.5 \%$ of MP joints.

TABLE NO. - 18 (RESTRICTIONS OF RANGE OF MOVEMENTS AT IP JOINT OF THUMB AT THE TIME OF FIXATOR REMOVAL)

\begin{tabular}{|l|l|l|}
\hline S. No. & & \\
\hline 1. & No difference. & 17 \\
\hline 2. & $0-30^{\circ}$ & 08 \\
\hline 3. & $30-60^{\circ}$ & 08 \\
\hline 4. & $60-90^{\circ}$ & 07 \\
\hline
\end{tabular}

At the time of fixator removal full movements were regains in $42.5 \%$ IP joint. 
TABLE NO. - 19 (RESTRICTION IN RANGE OF MOVEMENTS AT PIP JOINT AT THE TIME OF FIXATOR REMOVAL)

\begin{tabular}{|l|l|l|l|l|l|}
\hline S. No. & & 2. & 3. & 4. & 5. \\
\hline 1. & No difference & 16 & 21 & 23 & 23 \\
\hline 2. & $0-30^{\circ}$ & 11 & 09 & 06 & 07 \\
\hline 3. & $30-60^{\circ}$ & 08 & 06 & 07 & 04 \\
\hline 4. & $60-90^{\circ}$ & 05 & 04 & 04 & 06 \\
\hline
\end{tabular}

At the time of fixator removal $51.88 \%$ of PIP joints regained full movements.

TABLE NO. - 20 (RESTRICTION IN RANGE OF MOVEMENTS AT DIP JOINT AT THE TIME OF FIXATOR REMOVAL)

\begin{tabular}{|l|l|l|l|l|l|}
\hline S. No. & & 2. & 3. & 4. & 5. \\
\hline 1. & No difference & 17 & 25 & 24 & 25 \\
\hline 2. & $0-15^{\circ}$ & 15 & 09 & 10 & 08 \\
\hline 3. & $15-30^{\circ}$ & - & 01 & 01 & - \\
\hline 4. & $30-45^{\circ}$ & 08 & 05 & 05 & 07 \\
\hline
\end{tabular}

At the time of fixator removal full movements were regained by $56.88 \%$ of DIP joints.

TABLE NO. - 21 (RESTRICTION IN RANGE OF MOVEMENTS AT WRIST JOINT AT THE TIME OF FIXATOR REMOVAL)

\begin{tabular}{|l|l|l|}
\hline S. No. & & \\
\hline 1. & No difference & 16 \\
\hline 2. & $0-50^{\circ}$ & 07 \\
\hline 3. & $50-100^{\circ}$ & 10 \\
\hline 4. & $>100^{\circ}$ & 07 \\
\hline
\end{tabular}

At the time of fixator removal $40 \%$ of wrist joints regained full movements.

TABLE NO. - 22 (RESTRICTION IN RANGE OF MOVEMENT OF MP JOINT AT THE TIME OF FINAL FOLLOW-UP)

\begin{tabular}{|l|l|l|l|l|l|l|}
\hline S. No. & & 1 & 2 & 3 & 4 & 5 \\
\hline 1. & No difference & 22 & 17 & 21 & 21 & 21 \\
\hline 2. & $0-30^{\circ}$ & 16 & 18 & 15 & 15 & 14 \\
\hline 3. & $30-60^{\circ}$ & - & 03 & 02 & 02 & 03 \\
\hline 4. & $60-90^{\circ}$ & 02 & 02 & 02 & 02 & 02 \\
\hline
\end{tabular}

At the time of final follow up, 51\% of MP joints regained full movements.

TABLE NO. - 23 (RESTRICTION IN RANGE OF MOVEMENTS AT IP JOINT OF THUMB AT THE TIME OF FINAL FOLLOW-UP)

\begin{tabular}{|l|l|l|}
\hline S. No. & & \\
\hline 1 & No difference & 27 \\
\hline 2 & $0-30^{\circ}$ & 08 \\
\hline 3 & $30-60^{\circ}$ & 03 \\
\hline 4 & $60-90^{\circ}$ & 02 \\
\hline
\end{tabular}


At the time of final follow up $67.5 \%$ of IP joints regained full movements.

TABLE NO. - 24 (RESTRICTION IN RANGE OF MOVEMENTS AT PIP JOINT AT THE TIME OF FINAL FOLLOW-UP)

\begin{tabular}{|l|l|l|l|l|l|}
\hline S. No. & & 2 & 3 & 4 & 5 \\
\hline 1 & No difference $^{\circ}$ & 26 & 28 & 28 & 29 \\
\hline 2 & $0-30^{\circ}$ & 08 & 07 & 07 & 04 \\
\hline 3 & $30-60^{\circ}$ & 04 & 03 & 03 & 05 \\
\hline 4 & $60-90^{\circ}$ & 02 & 02 & 02 & 02 \\
\hline
\end{tabular}

At the time of final follow up $69.38 \%$ of PIP joint regained full movements.

TABLE NO. - 25 (RESTRICTION IN RANGE OF MOVEMENTS AT DIP JOINT AT THE TIME OF FINAL FOLLOW-UP)

\begin{tabular}{|l|l|l|l|l|l|}
\hline S. No. & & 2 & 3 & 4 & 5 \\
\hline 1. & No difference & 27 & 31 & 30 & 31 \\
\hline 2. & $0-15^{\circ}$ & 08 & 06 & 07 & 04 \\
\hline 3. & $15-30^{\circ}$ & 02 & 01 & 01 & 03 \\
\hline 4. & $30-45^{\circ}$ & 03 & 02 & 02 & 02 \\
\hline
\end{tabular}

At the time of final follow up $74.38 \%$ of DIP joint regained full movements.

TABLE NO. - 26 (RESTRICTION IN RANGE OF MOVEMENTS AT WRIST JOINT AT TIME OF FINAL FOLLOW-UP)

\begin{tabular}{|l|l|l|}
\hline S. No. & & \\
\hline 1. & No difference & 23 \\
\hline 2. & $0-50^{\circ}$ & 11 \\
\hline 3. & $50-100^{\circ}$ & 03 \\
\hline 4. & $>100^{\circ}$ & 03 \\
\hline
\end{tabular}

At the time of final follow up $57.5 \%$ of wrist joints regained full movements.

TABLE NO. - 27 (GRIP STRENGTH AT FINAL FOLLOW-UP)

\begin{tabular}{|l|l|l|l|}
\hline S. No. & Grip strength & Cases & Percentage \\
\hline 1 & Normal & 20 & 50.0 \\
\hline 2 & Mild deficient & 12 & 30.0 \\
\hline 3 & Moderate deficient & 06 & 15.0 \\
\hline 4 & Severely deficient & 02 & 05.0 \\
\hline Total & & 40 & 100.00 \\
\hline
\end{tabular}

The grip strength at final fallow up was Normal in $50 \%$ of cases while mildly deficient in $30 \%$ of cases. 
TABLE No. -28

\begin{tabular}{|l|l|l|l|}
\hline S. No. & Results & No. of patients & Percentage \\
\hline 1 & Excellent & 29 & 72.5 \\
\hline 2 & Good & 08 & 20.0 \\
\hline 3 & Fair & 01 & 02.5 \\
\hline 4 & Poor & 02 & 05.0 \\
\hline Total & 40 & 100.00 \\
\hline
\end{tabular}

In our study results were excellent in $72.5 \%$ of cases, Good in $20 \%$ of cases, fair in $2.5 \%$ of cases \& poor in $5 \%$ of cases.

- In our study results were excellent in $72.5 \%$ of cases, Good in $20 \%$ of cases, fair in $2.5 \%$ of cases \& poor in $5 \%$ of cases.

DISCUSSION: The functional outcome of the fractures of small bones of hand is in part dependent, on severity of injury and initial management. Comminuted, contaminated, displaced open fractures combined with soft tissue and segmental bone loss is one of the most severe of all hand injuries.

Different types of JESS frame[1] were applied in 40 patients of hands and forearm injuries in our study. Out of 40 patients, 36 were males while 4 were females, with the mean age of presentation 32 years (range 11 to 67 years).

The modes of injury in our study were mainly thresher/ machine work injuries, road traffic accidents, followed by fall of heavy objects. Out of 40 patients, 21 have injuries involving the right hand, while in 19 left hand was involved.

The fractures were open in 34 patients, and closed in 6 patients.

We observed 100 fractures in 40 patients, out of which 50 (50\%) were metacarpals, 32 (32\%) were phalanges and 9 (9\%) were radius and ulna. Phalanges were the most common bones involved in isolated injury, while the metacarpals were the most common bone involved in combined injuries.

We applied the principle of ligamentotaxis ${ }^{[1]}$ to achieve reduction in these cases. We applied extended hand frames and basic hand frames in multiple injuries of hands, so that each bone of hand can be fixed, with minimum obstruction of joint movements of uninvolved bones.

In present study majority of fixators were removed within 6 weeks and in 29(70\%) patients wounds were healed at that time. Fractures were united in $37(90 \%)$ patients at the time of fixator removal.

The incidence of non union in our study was 7\%.Most common complication observed in present study were deformities of injured part(45\%) followed by swelling(25\%).We observed deformities in 18 cases out of which 12 had mild deformities (mostly flexion deformity of MP joint). Active exercises with gripper were advised for improvement of the strength of intrinsic muscles of hand.

At the final follow up 51\% of MP joints, $68 \%$ of IP joints, $70 \%$ of PIP joints, $74 \%$ of DIP joints and $58 \%$ wrist joints regained their normal movements.

In the present study of 40 patients, grip strength was normal in 20 cases, mildly deficient in 12 cases, moderately deficient in 6 cases and severely deficient in 2 cases.

The results in our study were graded as Excellent in 29 cases(72.5\%), Good in 8 cases(20\%), Fair in $1(2.5 \%)$ and Poor in 36 out of 40 were satisfied with their results.2 (5\%). 
36 out of 40 were satisfied with their results. Schuind F et al[[2]conducted a study comprising of 26 patients ( 21 males \& 5 females). Parson et a also did a prospective study of 30 patients, out of which 26 were male \& 4 female, with the mean age of 28 yrs. In the study by Mullet JH et al [4](in 33 patients, the mean age was 35 yrs. (range 15-69 yrs) with male predominance (27males \& 6 females). Steven et al[ ${ }^{[5]}$ did a retrospective study comprising of 86 patients, out of which 75 were males \& 11 females with mean age was 32 years (range 14-76 yrs). Von Oosterom et al[6]in a study of 350 patients, 315 were males \& 35 females. With mean age was 35 yrs (range 8-80 yrs).

The modes of injury in our study were mainly thresher/ machine work injuries, Road traffic accident, followed by fall of heavy objects. Out of 40 patients, 21 have injuries involving the right hand while in 19, left hand. Parson et al (1992) found wide variety of mechanism of injury in their study ranging from acute sudden impact (as from punching or crushing) to industrial works. Mullet et al [4] observed that the most common mode of injury was road traffic accident and injury due to machine and fall of heavy objects.

The fractures were open in 34 patients while closed in 6 patients, out of 40 patients in our study.

Pritsch et al[7] reviewed 36 metacarpal fractures out of which two were open type. Riggs and Cooner ${ }^{[8]}$ reported their experience with the Jacquet mini-fixator in 10 hand fractures, 3 of which were open. Sietz et al[9]reported on 26 hand fractures in 22 patients, of which 18 were open fractures. Freeland et al[10]had reported on the use of external fixation in 20 open hand injuries in 12 patients. Ashmead et al[11]reported 35 cases of hand injuries out of which 12 had open type of fractures. Parsons et al[3]reported 9 open fractures out of 37 fractures in 30 patients, 6 of them also had tendon injuries. Mullet et al[4]reported 27 patients, out of 33 having open type injuries, in 12 patients one or more tendon was partially or completely involved, Steven et al5 $5^{[5]}$ observed 105 fractures in 82 patients out of which 68 fractures were closed and 37 were open.

We observed 100 fractures in 40 patients, out of which 50 (50\%) were metacarpals, 32(32\%) were phalanges and 9(9\%) were radius and ulna were fractured, thus phalanges were the most common bones involved in isolated injury while the metacarpals were the most common bone involved in combined injuries.

Smith et al[12] observed 10 patients with 11 fractures of the proximal phalanx who were treated with the A0/ASIF small external fixator. 7 out of 11 fractures (5 IP joints and 2 MP joints) were intra-articular. Sameer et al (1991) found 7 fractures were intraarticular out of 11 phalangeal fractures and one out of 19 metacarpals fractures. Parson et al[3] studied 30 patients and concluded that metacarpals (23) were commonly involved in combined injuries followed by phalangeal fractures (14). Mullet et al[4]observed 36 fractures in 33 patients, out of 36, 29 phalanges and 7 metacarpals were fractured. Steven et al[5]observed 105 fractures in 82 patients out of which $66(63 \%)$ metacarpals and $39(37 \%)$ phalanges were fractured. Mullet $\mathrm{JH}^{[4]}$ found 30 intra-articular fractures and 9 extra-articular fractures out of 37 patients, 51\% fractures were intra-articular in his study.

We applied extended hand frames and basic hand frames in multiple injuries of hands so that each bone of hand can be fixed, with minimal obstruction of joint movements of uninvolved bones. 
In present study majority of fixators were removed within 6 weeks and in 29 patients $(70 \%)$ wounds were healed at that time. Fractures were united in $37(90 \%)$ patients at the time of fixator removal.

Bilos et al[13] observed 15 open phalangeal fractures, out of which 7 intra-articular fractures were united primarily with stable ankylosis and good digital alignment. 6 of the phalangeal shaft fractures were united primarily and one united after a delayed bone graft procedure. Pritsch et al[7]reviewed 36 metacarpal fractures treated with K-wire and acrylic cement external fixator. $100 \%$ union was observed at 5 wks. Freeland ${ }^{[10]}$ observed 20 open hand fractures in 12 patients and reported 3 fractures were managed with bone graft and converted to internal fixations 2-7 days after external fixation and one case required supplementary internal fixation \& bone grafting. $80 \%$ fractures united primarily while $20 \%$ required delayed bone grafting. Seitz et al ${ }^{[9]}$ reported $85 \%$ union rate at 8 weeks while non-union was present in 4 cases out of 26 hand fractures. Schuind F et al[2]in a similar study also observed that most of their patients had bony union within 12 weeks. Parson et ${ }^{\left[{ }^{[3]}\right.}$ reported union in all their patients, with metacarpal fractures (mean duration 4.8 weeks) \& phalangeal fractures (mean duration 4.5 weeks). Ashmead et al[11]treated 12 open fractures with external fixation. 10 united primarily while 1 required secondary bone grafting with subsequent bone union while one patient lost to follow up. Mullet et al[4] removed device at a mean duration of 6 weeks an also observed union in all patients but after a much longer duration of 28 weeks.

The incidence of non-union in our study was $7 \%$, i.e. higher than other studies. Most common complication observed in present study were deformity of injured part (45\%) followed by swelling in $25 \%$ of cases. Freeland et al[10] observed 20 open hand fractures in 12 patients and described two complications- Mild deformity (10\%) and ankylosis (55\%). Sietz et al[9] reported pin tract infections in 1 case and malunion in 1 case out of 22 patients. Green et al[14] observed that the incidence of pin site infection was $8.4 \%$, the incidence of ring sequestra at the pin site and osteomyelitis was approximately $0.2 \%$. Schuind $\mathrm{F}$ et al ${ }^{[2]}$ in their series of 26 patients treated with external fixator did not encounter any deformity, pin site infection, loss of reduction. Cziffer[15] observed a few minor wound problems and superficial pin tract infection in $4 \%$, no deep infection occurred in this study. Mullet et al[4] found complications in 10 fractures in the form of loosening of pin (in 6 patients), restriction of movements of adjacent fingers due to mechanical interference by the device ( 3 patients) and loss of reduction ( 1 patient).

We observed deformities in 18 cases, out of which 12 had mild deformities (mostly flexion deformity of MP joint). Active exercises with the gripper were advised, for improving the strength of small intrinsic muscles.

At the final follow up $51 \%$ of MP joints, $68 \%$ of IP joints, $70 \%$ of PIP joints, $74 \%$ of DIP joints, and $58 \%$ of wrist joints regained their normal movements. Freeland et al[10] observed loss of motion with all intra-articular fractures particularly those involving PIP joints. He recommends stabilizing these complex intra-articular fractures in a position of function, in anticipation of fibrous or complete ankylosis. Schuind $\mathrm{F}^{[2]}$ observed in 19 metacarpal fractures the percentage return of normal active range of movements varied from $77-100 \%$ with a mean return of $96 \%$.

Parsons et al ${ }^{[3]}$ observed good phalangeal functions in $94 \%$ of metacarpal and $85 \%$ of phalangeal fractures by 9 weeks. Mullet et al[4] evaluated results based on range of 
movements, along with residual pain and reported excellent results in 15 cases $(41.7 \%)$, good in 10 cases $(27.8 \%)$, fair in $3(8.3 \%)$ and poor in $8(22.2 \%)$.

In the present study of 40 patients, grip strength was normal in 20 cases, mildly deficient in 12 cases, moderately deficient in 6 cases and severely deficient in 2 cases.

Excellent in 29 cases (72.5\%), Good in 8 cases (20\%), fair in $1(2.5 \%)$ and poor in 2 (5\%). 36 of 40 patients were satisfied with their results.

\section{ADVANTAGES OF JESS:}

1. With the use of thin and smooth wires placed away from the site of injury in a stable configuration created by an exoskeleton of connecting system and link joints, it provides a stable skeletal environment aiding rapid healing of soft tissues.

2. The system is simple and modular; it assists the surgeon in obtaining tissue stabilization, spontaneous revascularization, and tissue expansion by gradual and controlled distraction.

3. Limiting the frame configuration to the involved bone alone allows immediate mobilization of adjacent joint, thus restoring circulation and prevents lymph's or venous stasis leading to lesser incidence of infections.

4. Ability to add dynamic component into the frame and permit concurrent mobility of the joints of the injured hand since mobilization keeps the gliding structures moving, functional restoration is expedient.

5. Precise positioning of the hand allows tissue transfer, tissue transplants, or other reconstructions with simultaneous correction of relingment and joint mobilization.

6. Joint space and alignment of articular surfaces are maintained by ligamentotaxis in inta articular fracture.

7. In case of bone loss better maintenance of length was achieved, the patients hand can be immobilized in functional position, so chances of stiffness in non functional position is much less as compared to immobilization in POP slab.

8. It allows repeated wound infection, cleaning and dressing without change of position, during the healing stages.

9. It allows aeration under the dressing and thus prevents sweating and maceration of tissues which may cause secondary infection of graft area.

10. Transarticular wire fixation can cause infective arthritis. K-wires in JESS are extraarticular, thus avoid this complication.

11. It is light and patient friendly, in comparison to the fixation carried out by plaster cast or splints.

\section{DISADVANTAGES OF JESS:}

1. Pin site drainage, pin tract infection, pin loosening, ring sequestrum at the pin site with osteomyelitis because of open injuries.

2. Neurovascular and musculotendinous injury.

3. Malunion and non union, if fixator not assembled properly.

CONCLUSION: For hand injuries JESS is a cheap, technically less demanding and an effective procedure. This procedure not only corrects the deformity but at the same time keeps the joint 
surface apart, thereby avoiding any crushing force on bone cartilage. Also this being semi invasive procedure, it does not require bone and soft tissue resection.

\section{BIBLIOGRAPHY:}

1. Dr. B.B. Joshi (1976) : Percutaneous internal fixation of fractures of the proximal phalanges. The Hand Surg 8;86

2. Schuind $F$ et al (1991) : External minifixation for treatment of closed fractures of the metacarpol bone. J Ortho Traumat, 1991, 5(2) p. 146-52.

3. Parsons SW, Fitzgerald JA, Sherare JR : External fixation of unstable metacarpal and phalangeal fractures. J Hand Surg (Br.), 1992; Apr : 17(2) : 151-5.

4. Mullet JH, Synott K, Noel J, Kelly EP : Use of the "S" Quattro dynamic external fixation in eth treatment of difficult hand fractures. J Hand Surg (Br), 1999 Jun, 24(30) :350-4

5.Stephen et al;(1998); external fixation in compound injuries of hand and foot.

6. Von Oosterom et al : Treatment of phalangeal fractures in severely injured hands. J Hand Sirgery (Bri \& Eu) 2001, $2613: 2: 108 ; 111$

7. Pritsch M, Engel J and Farin I (1981) : Manipulation and external fixation of metacarpal fractures. Journal of Bone and Joint Surgery, 63A: $8: 1289-1291$

8. Riggs SA, Cooney WP : External fixation of complex hand and wrist fractures, J Trauma 23: 332-336, 1983.

9. Seitz WH, Gomag W Putnam MD et al : The management of severe habd trauma with a miniexternal fixator. Orthopaedics 10(4) :601, 1987

10. Freeland AE, Jabaley ME : External fixation for skeletal stabilization of severe open fractures of the hand. Clin Orthop 214: 93-100, 1987.

11. Ashmead D 4th, Rothkopf DM, Walton RL, Jupiter JB : Treatment of hand injuries by extenal fxatn. J Hand Surg Am; 1992 Sep; 17(5) : 954-54

12.Smith RS, Alonso J, Horowitz M : External fixation of open comminuted fractures of the proximal phalanx. Orthop Rev. 1987Dec; 16(12); 937-41

13. Bi;os ZL, Eskestrand $\mathrm{T}$ : External fixator in comminuted gunshot fractures of the proximal phalanx. J Hand Surg (Am), 1979, Jull 4(4) : 357-912.Smith RS, Alonso J, Horowitz M : External fixation of open comminuted fractures of the proximal phalanx. Orthop Rev. 1987Dec; 16(12); 937

14. Green SA : Complications of pin and wire external fixation AAOS instructional course fractures. 39: 219, 1990.

15. Criffer E : The use of the manuflex disposable mini-external fixator. Orthopaedics 1989, Jan; $12(1): 163-6$ 

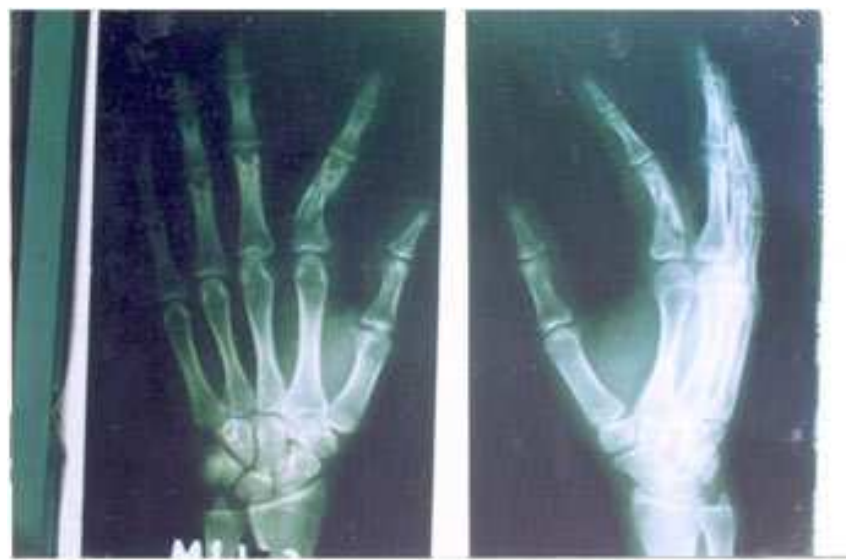

Fracture proximal phalanx index finger
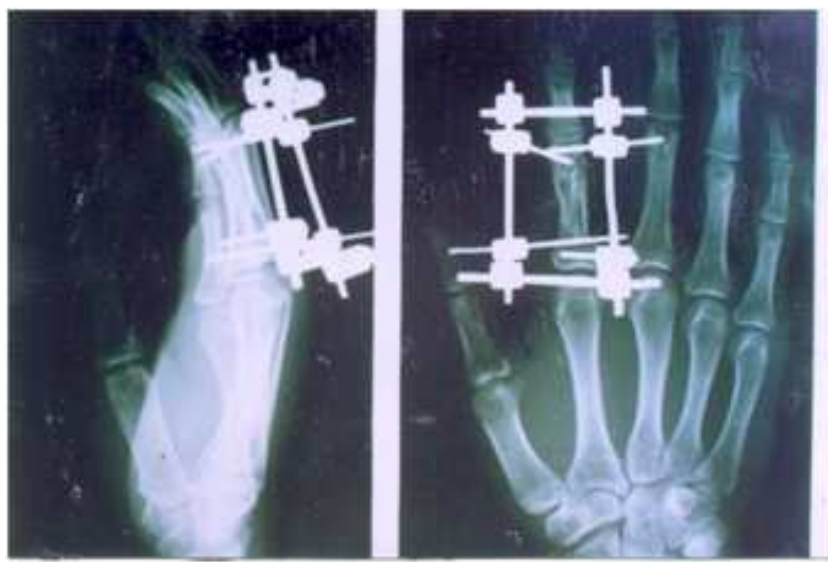

jess frame for the patient

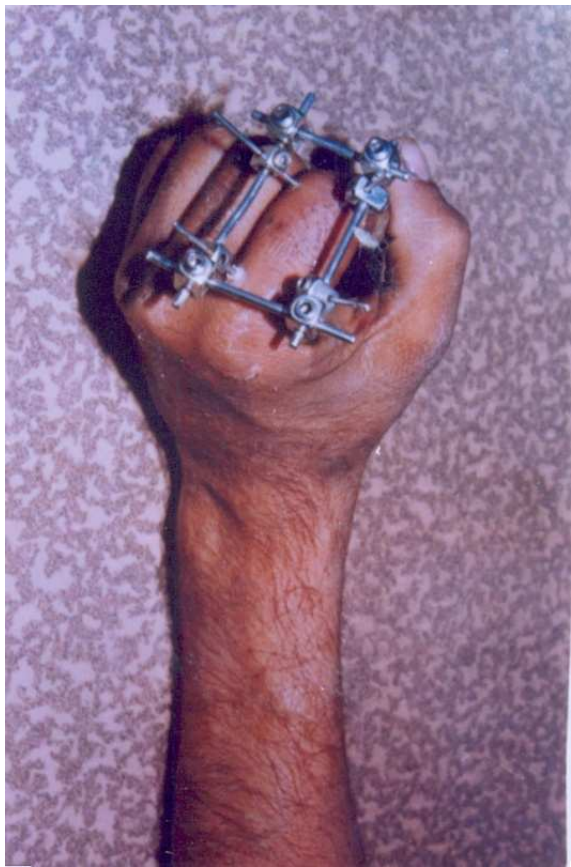

Patient with jess frame full grip movement 


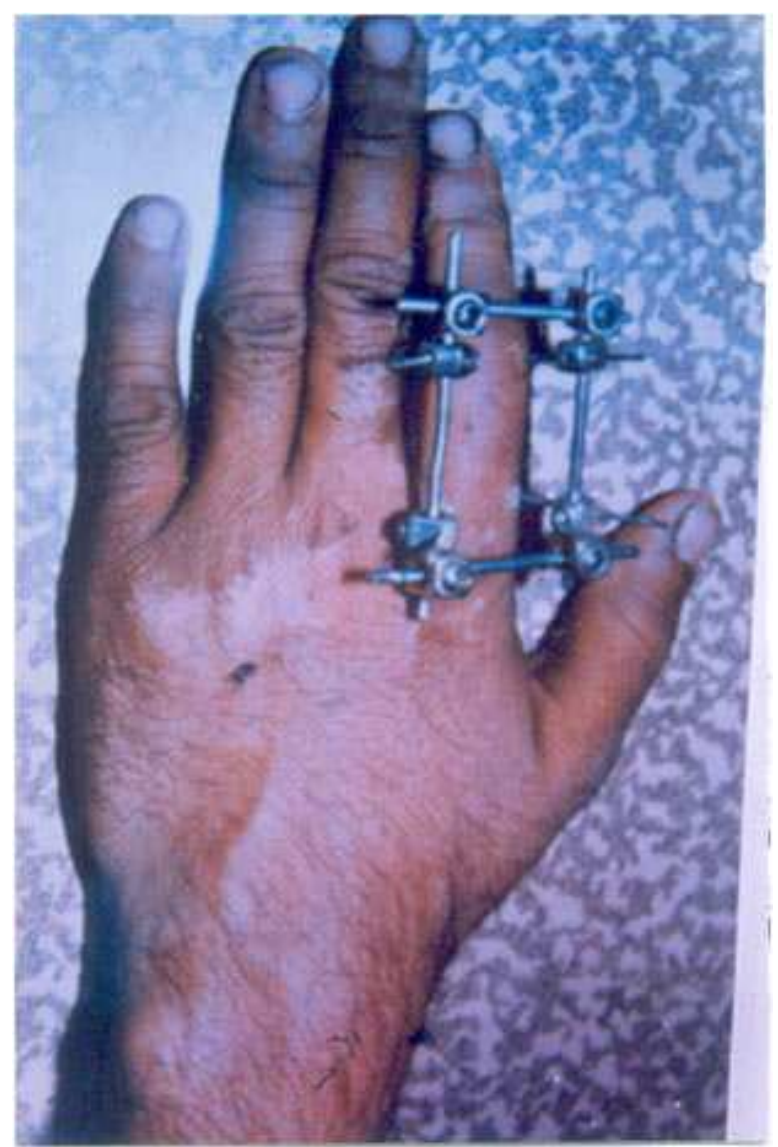

Same patient with extended finger
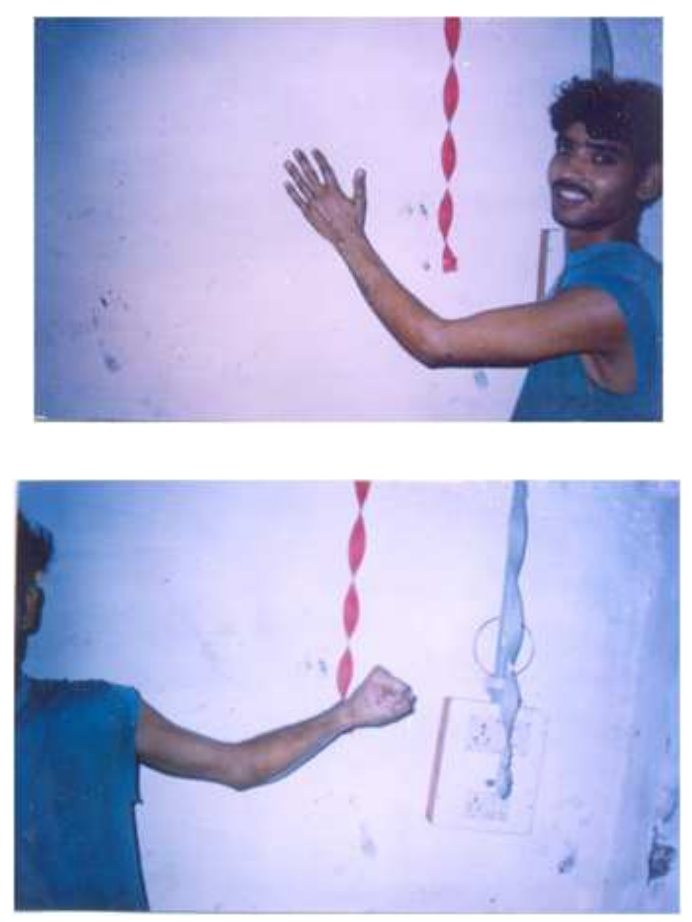

Full grip movement 


\section{ORIGINAL ARTICLE}

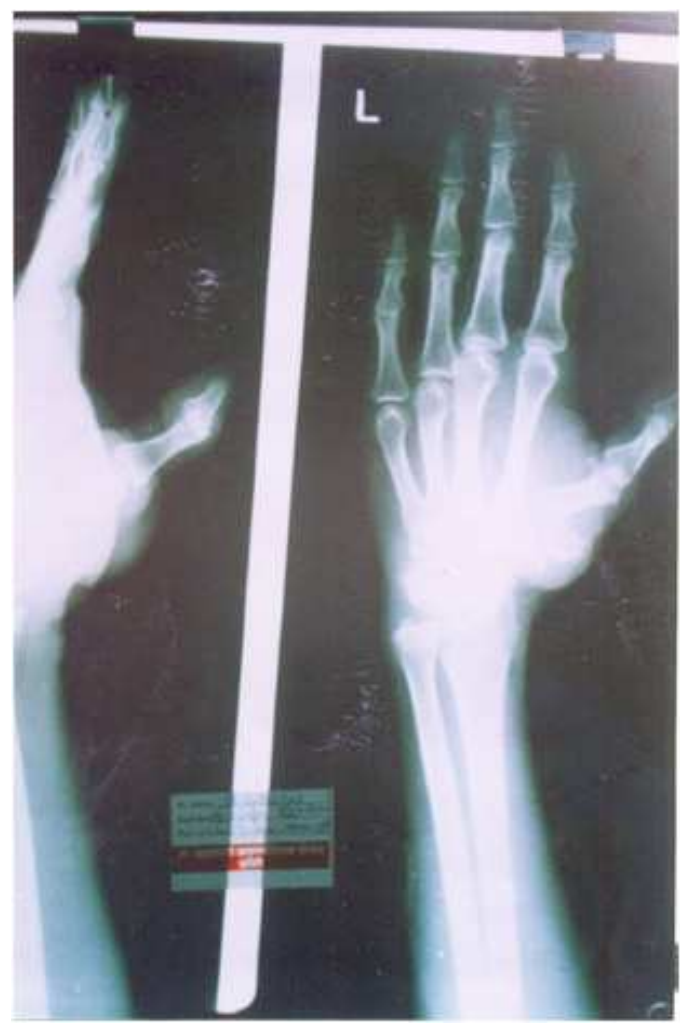

Bennet's fracture dislocation
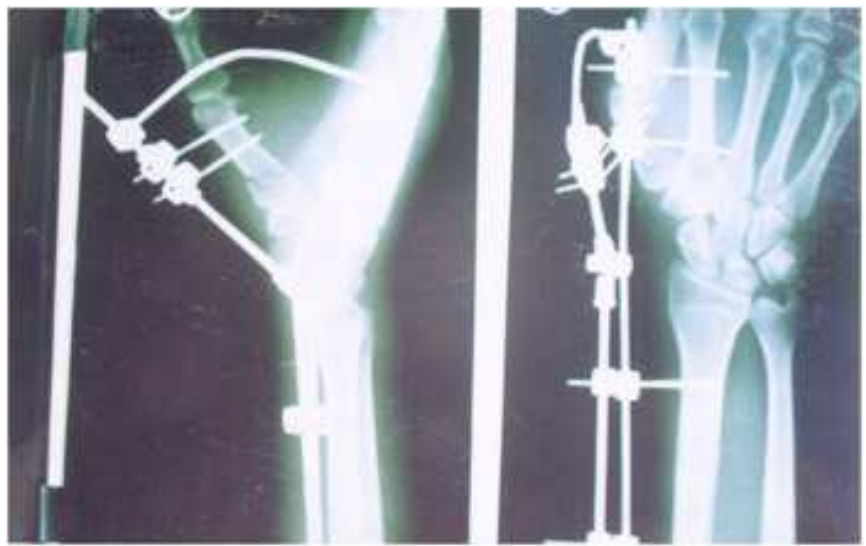

Same patient with jess frame 


\section{ORIGINAL ARTICLE}

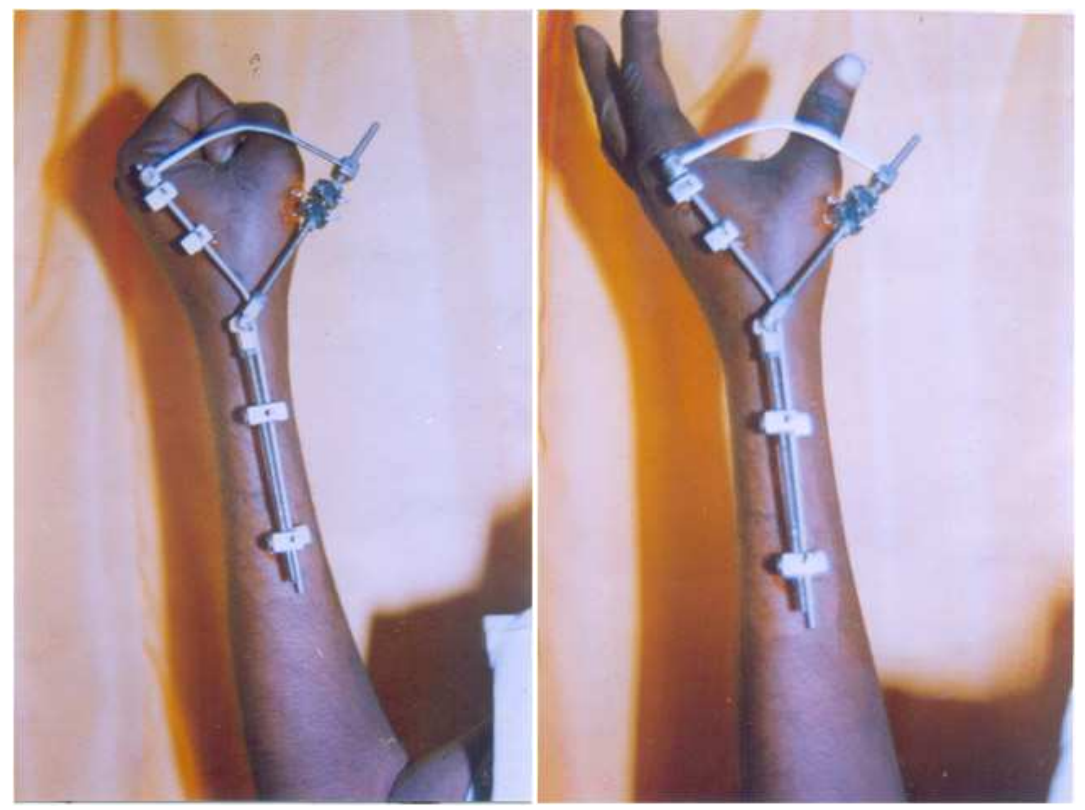

Full grip movement with jess extention movement
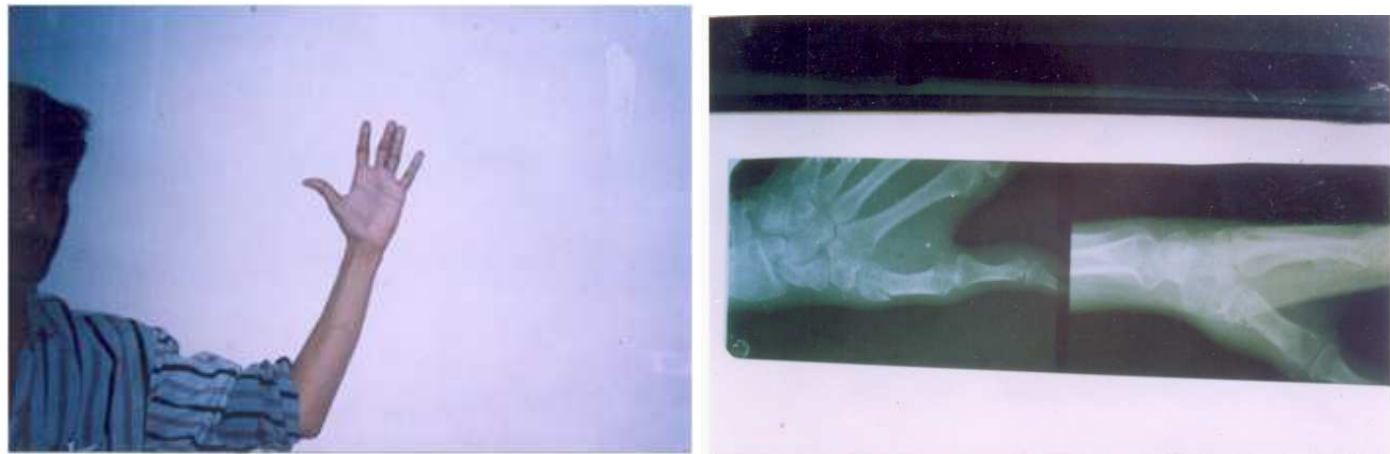

Same patient after jess removed $\mathrm{x}$ ray showing union
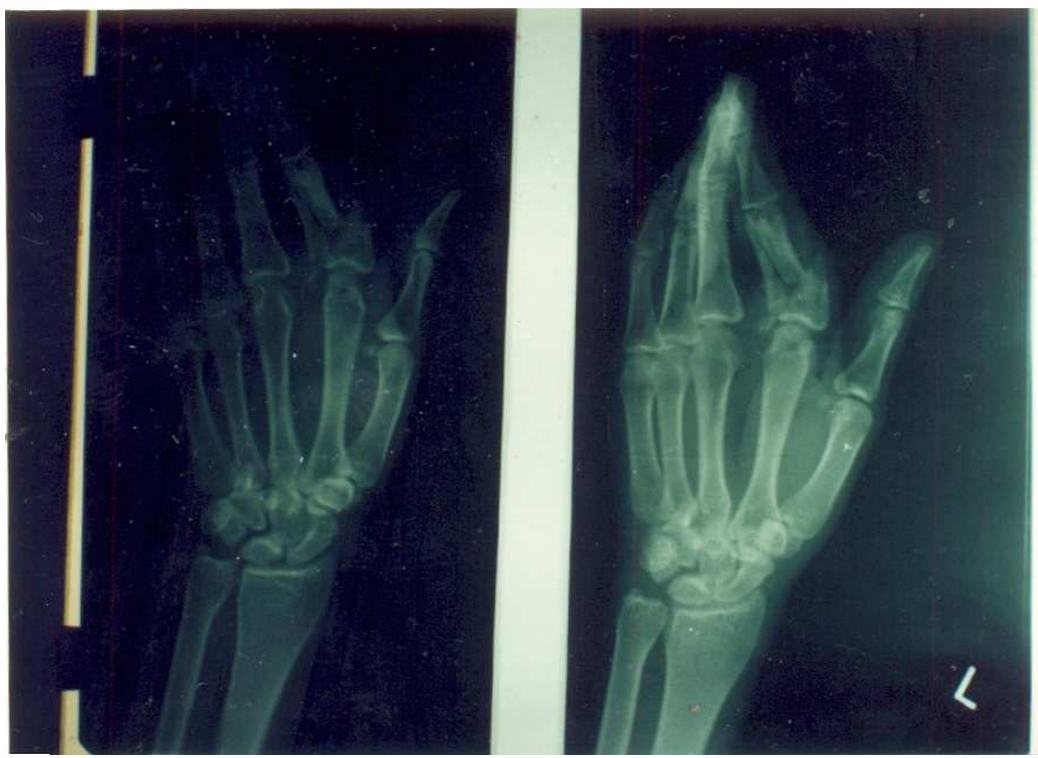

Comminuted fracture proximal phalenx index finger 


\section{ORIGINAL ARTICLE}

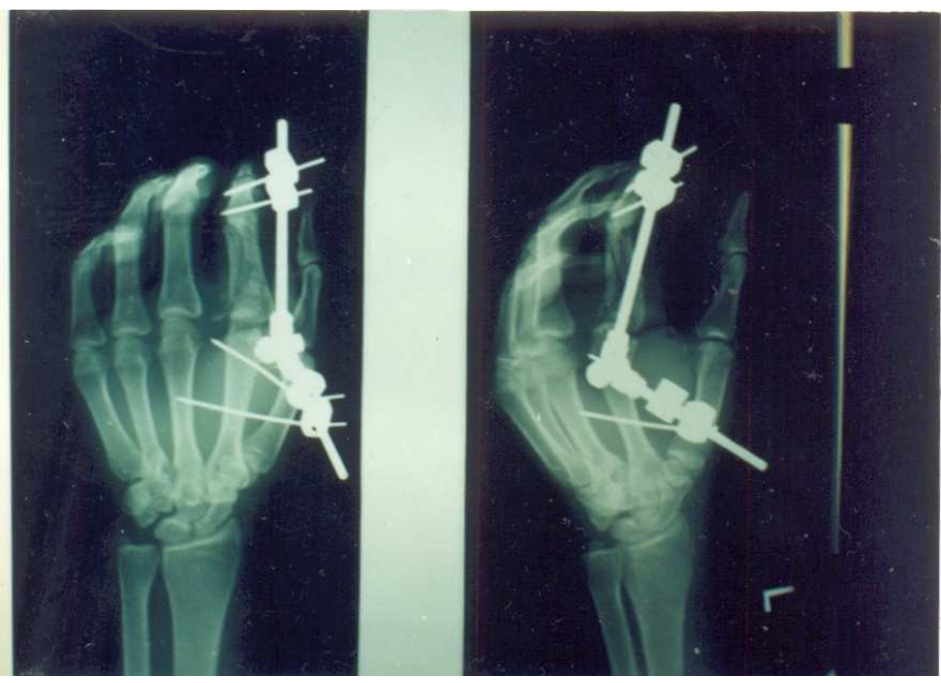

jess frame

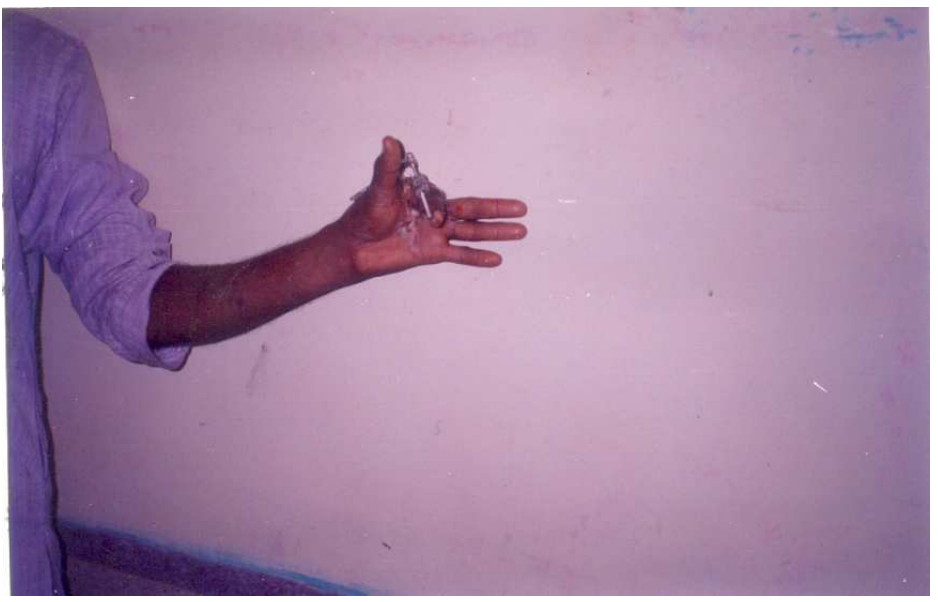

Movement with jess

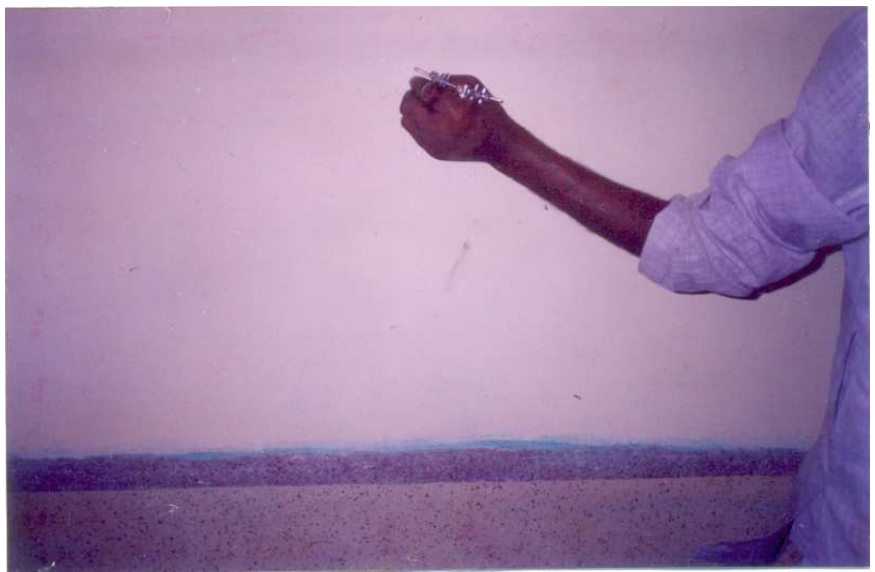

Gripping with jess 


\section{ORIGINAL ARTICLE}

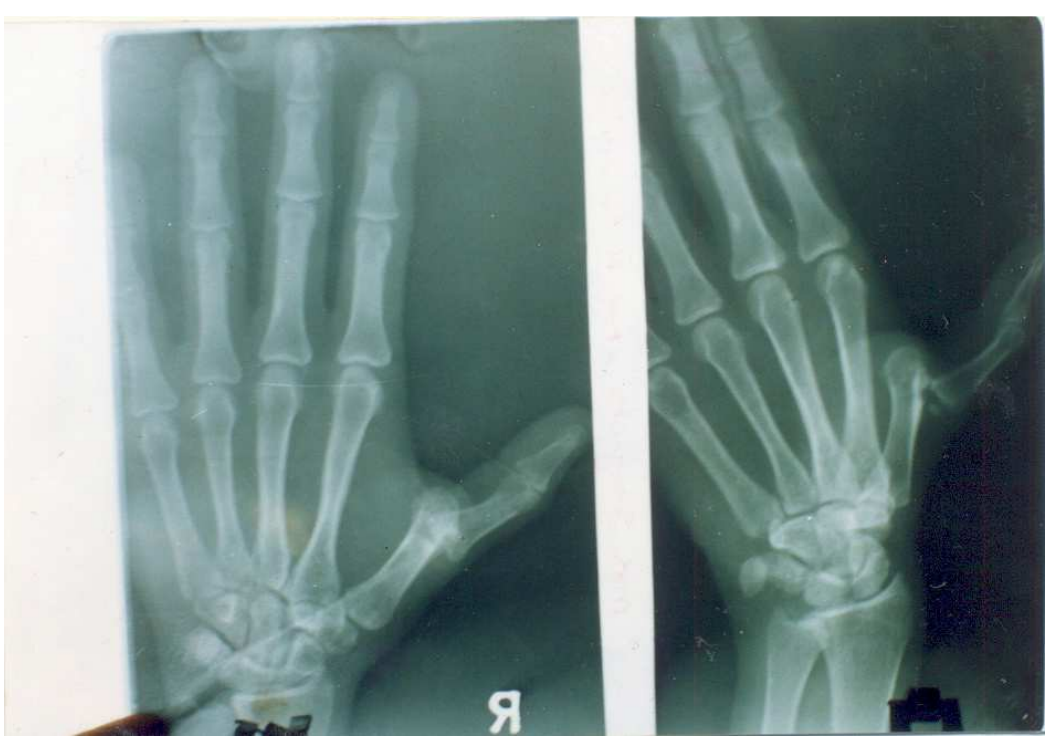

Dislocated 1st metacarpophalangeal joint

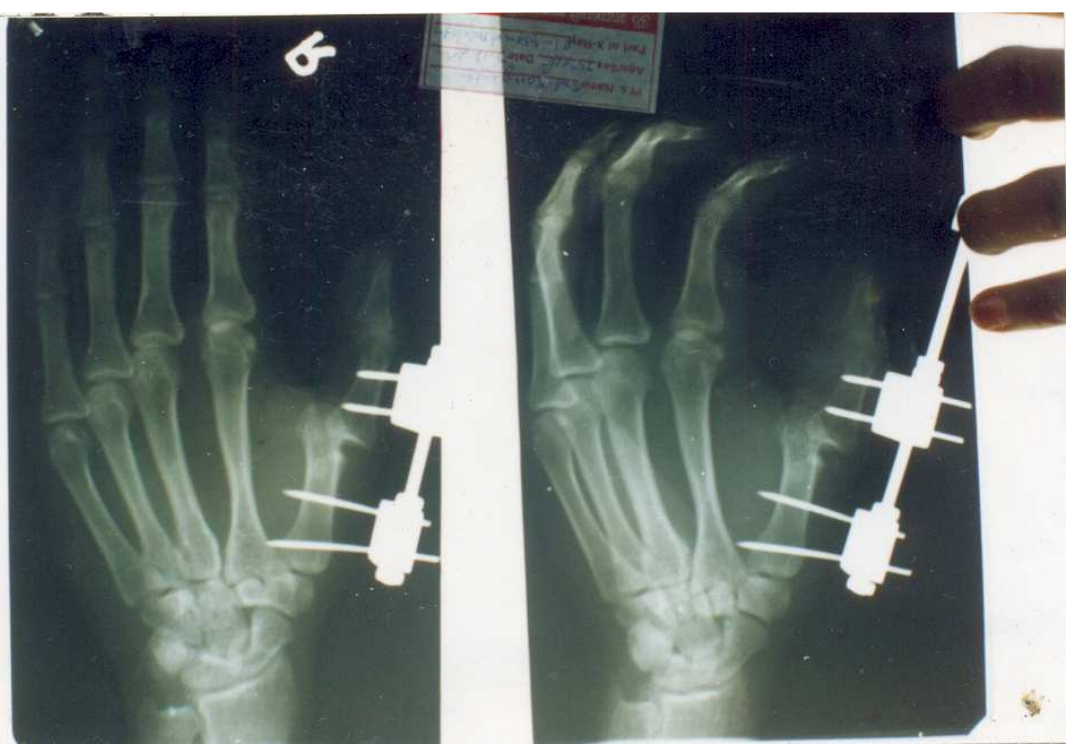

Gradual reduction with distractor

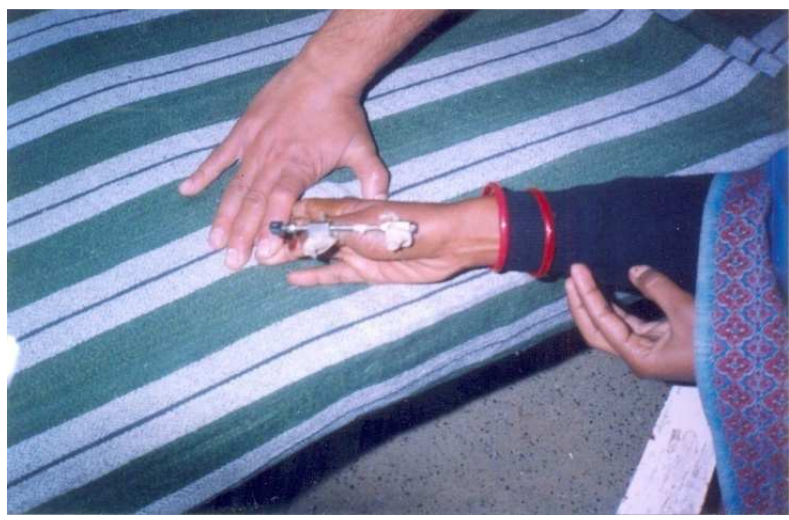

Patient with distractor 


\section{ORIGINAL ARTICLE}

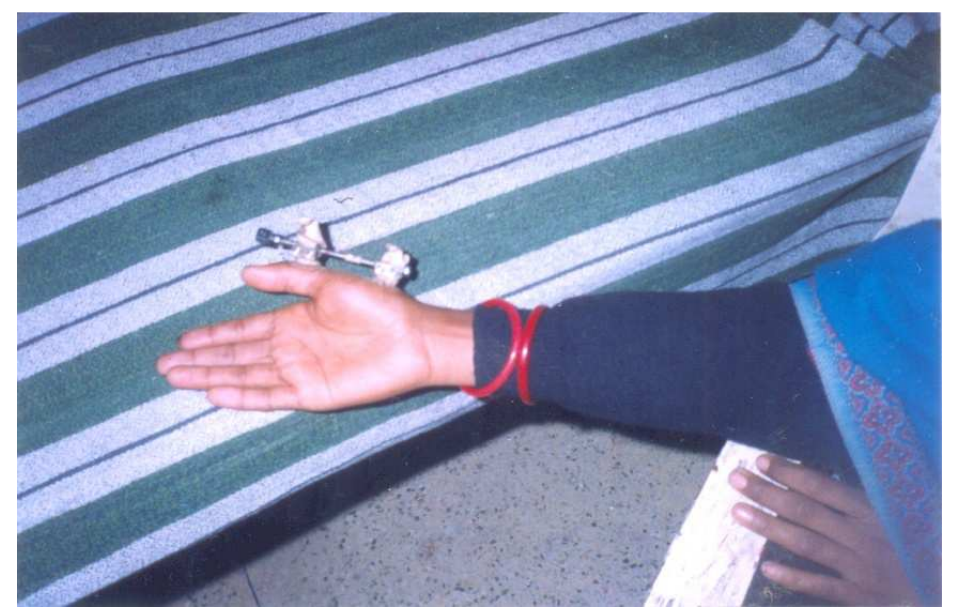

Patient with distractor2
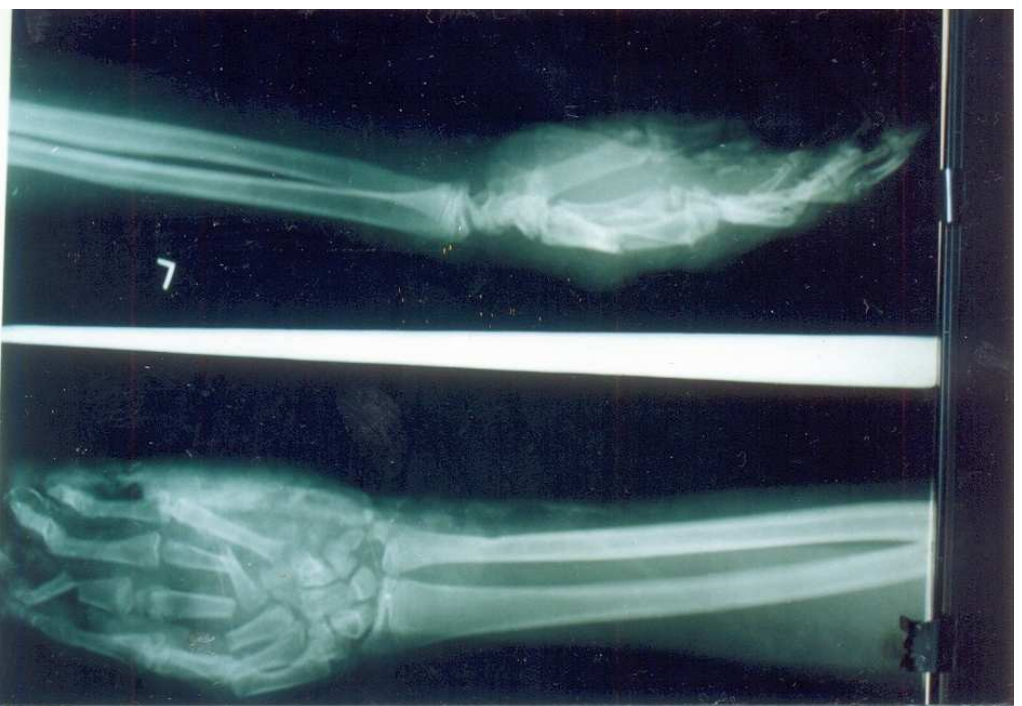

Crush injury hand

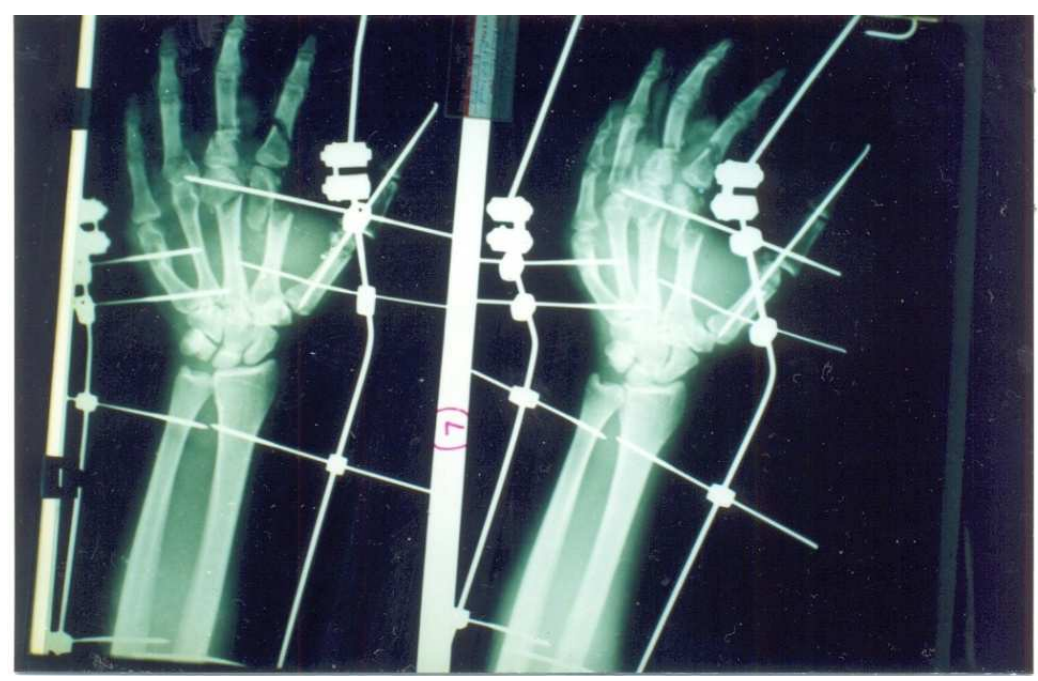

jess applied in crush injury hand 


\section{ORIGINAL ARTICLE}

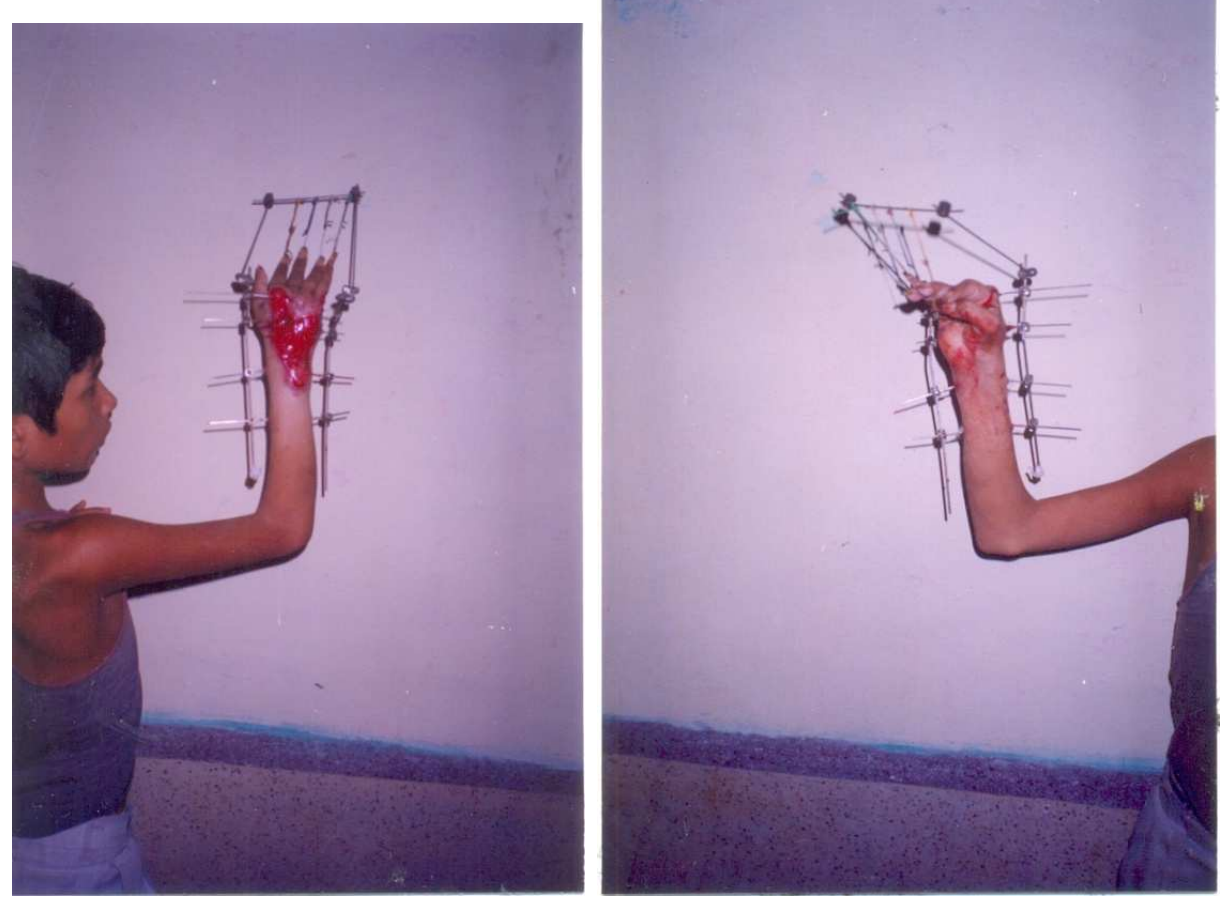

Patient with jess in crush injury hand same pt.

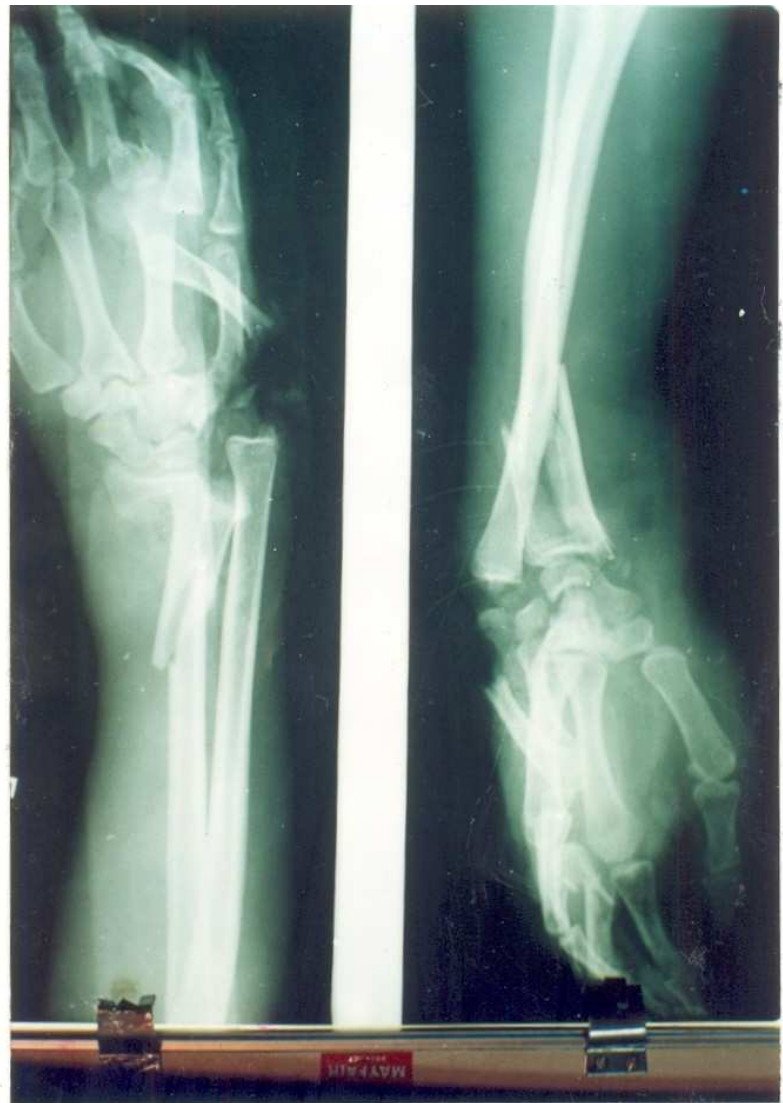

Thresher injury hand 


\section{ORIGINAL ARTICLE}

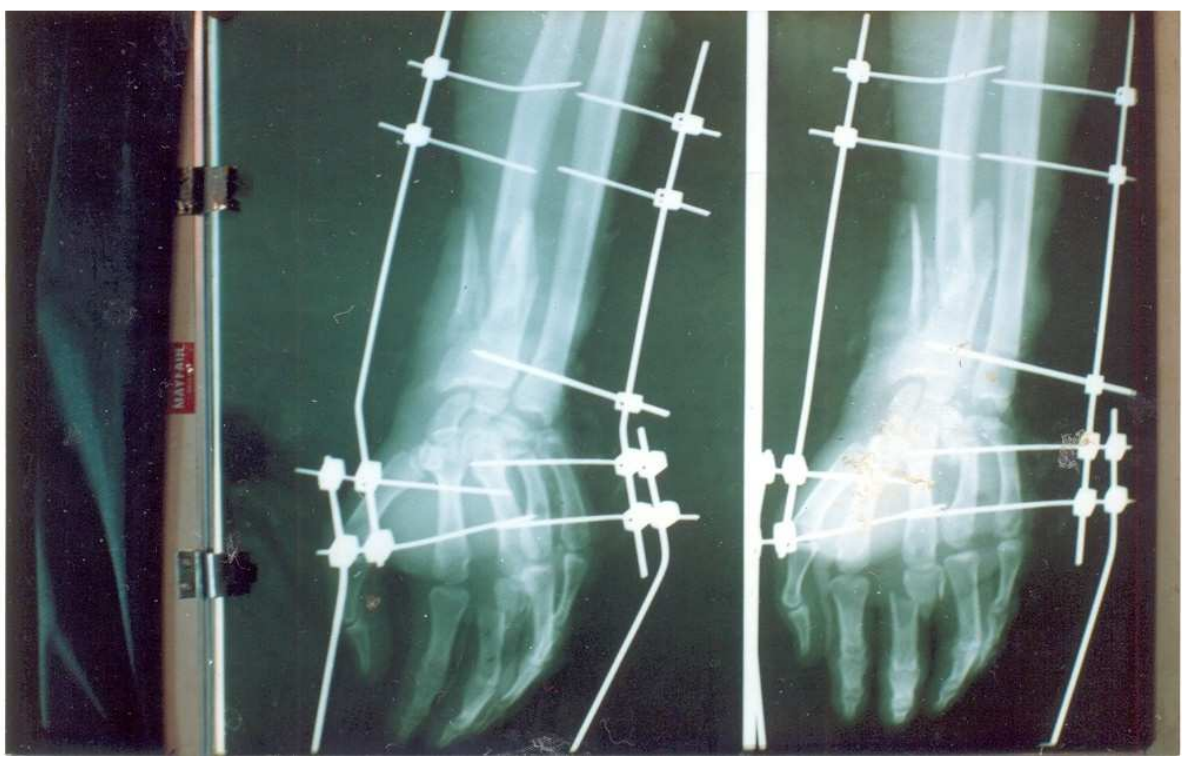

Thresher injury with jess applied
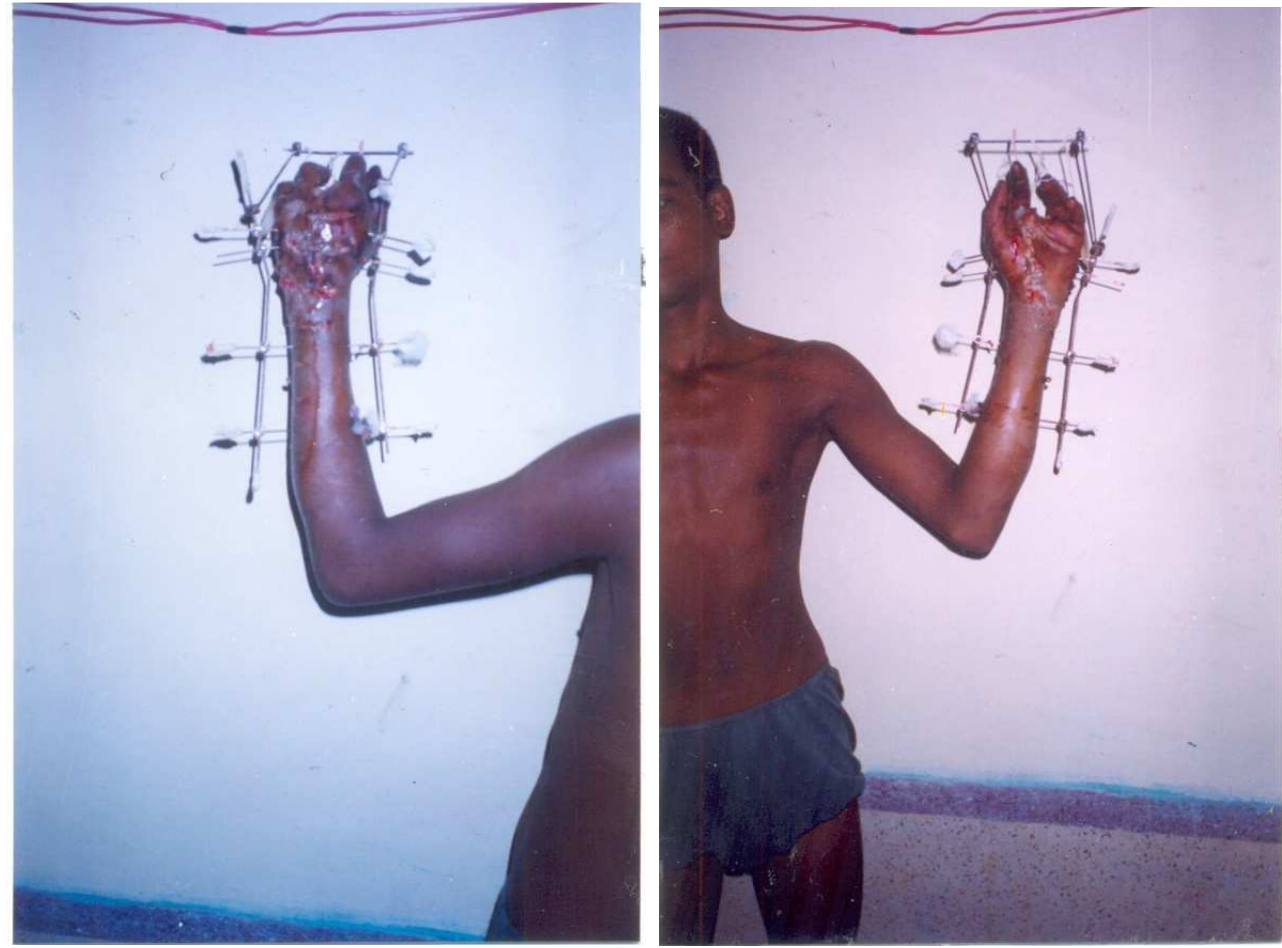

Same patient with thresher injury 


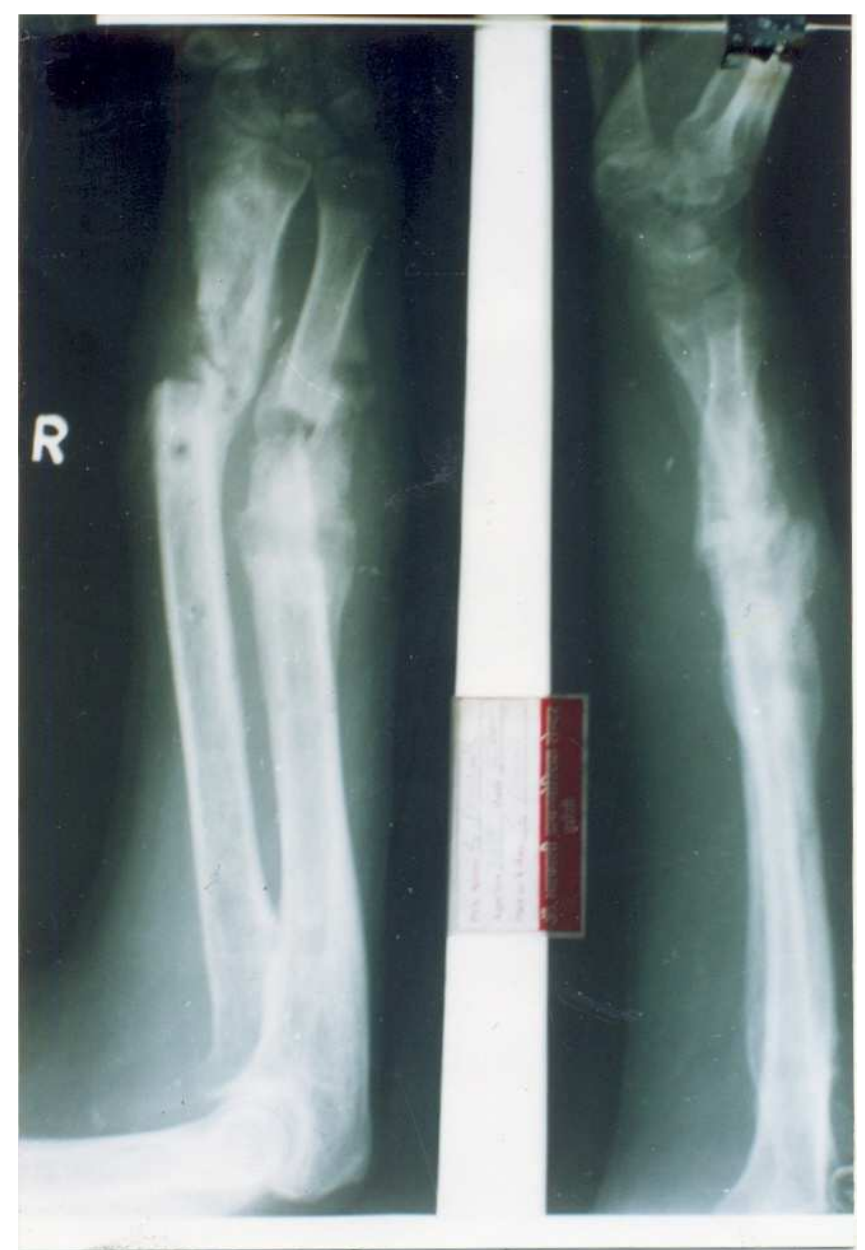

Union after 3 months 